\title{
KONSEP PEMIKIRAN IBNU SINA TENTANG PENDIDIKAN AKHLAK
}

\author{
Deswita \\ Program Studi Pendidikan Agama Islam, Jurusan Tarbiyah, STAIN Batusangkar \\ Korespondensi: J1. Lasykar No.80 Koto Gadih Lima Kaum, Batusangkar, Sumatera Barat \\ email: deswita.ma@yahoo.com
}

\begin{abstract}
In this article, the researcher tried to discuss the thinking way of Ibnu Sina about Islamic education, especially in teaching behaviour. It was due to teaching behaviour was the basic principle to achieve the target of teaching. For Ibnu Sina, the teaching behaviour could be explored through discussion and socialization among the children of the same age. It was because they had a sense of imitation. In teaching bahaviour, a teacher had to consider the children's psychology because this might influence the successful of teaching. Meanwhile, as a medium of teaching behaviour, Ibnu Sina had used a poem as a tool to spread the value of good behaviour.
\end{abstract}

Kata kunci: pemikiran, pendidikan, akhlak

\section{PENDAHULUAN}

$\mathrm{D}$ alam perjalanan sejarah, perkembangan pendidikan Islam mengalami beberapa hambatan, tantangan, atau bahkan kemandegan. Ini terbukti dari adanya perbedaan antara idealitas yang dicita-citakan dengan realitas yang diterapkan dalam sistem pendidikan Islam. Pendidikan Islam adalah dasar yang kokoh bagi umat Islam dengan berbagai tujuaan yang relevan dari beberapa aliran dan tokoh baik masa lalu maupun modern pada dunia pendidikan dewasa ini.

Dalam pandangan yang berkembang dalam masyarakat umum, pendidikan nasional dalam berbagai jenjang menengah dan tinggi, dianggap "telah gagal" dalam membentuk peserta pendidik yang memiliki moral, akhlak, dan bundi pekerti yang baik. Lebih jauh lagi, banyak peserta didik dinilai tidak hanya kurang memiliki kesantunan, baik di sekolah maupun dalam masyarakat, tetapi juga terlibat daloam tindak kekerasan, seperti tawuran.

Kegagalan dalam penanaman nilainilai serta pembangunan mental anak dan lain-lainnya saat ini telah kita rasakan bersama. Tawuran antar pelajar, serta yang lebih parah, maraknya perilaku seksual dikalangan remaja, ini merupakan potert dari kegagalan pendidikan dalam mentransformasikan nilainilai sebagai pusat pemberdayaan manusia. Lemahnya bekal keagamaan seperti ini pada gilirannya akan melahirkan individu-individu lemah moral yang kehilangan eksistensinya sebagai manusia sejati yang selalu dilandasi oleh smangat kejujuran.

Islam sangatlah memperhatikan segala macam pendidikan manusia, terutama pendidikan rohani, agama, dan budi pekerti. Dalam konteks ini, tampak nyata bahwa pendidikan Islam berusaha mengembangkan aspek-aspek dalam kehidupan manusia, yang meliputi: aspek spiritual, intelektual, imajinasi, keilmiah- 
an, dan aspek lainnya, untuk keselarasan kehidupan. (Aden Wijdan dan Muslih Usa, 1997).

Usaha untuk mencapai tujuan ini, telah dicoba direalisasikan umat Islam sejak zaman kejayaan Islam. Hal ini ditandai dengan kemunculan cendikiawan dan ulama muslim termasyhur seperti Ibnu Sina, Al-Farabi, Ibnu Khaldun dan yang lainnya.

Bagi Ibnu Sina, perhatian terhadap kehidupan manusia dalam masyarakatnya sangatlah penting, sehingga ide dan pemikirannya dalam pendidikan didasarkan atas orientasi masa depan, dan bagaimana individu harus menjalani hidup dan kehidupannya dengan masyarakat melalui pendidikan.

Ibnu Sina merupakan tokoh besar dunia Islam yang memiliki pengaruh sangat luas, tidak hanya di dunia Islam, tetapi juga di dunia Barat. Cakupan keahliannya pun cukup luas, mulai kedokteran, filsafat, hukum Islam, hingga pendidikan. Dengan demikian, merupakan kajian yang menarik untuk memaparkan konsepsi pemikiran Ibnu sina tentang pendidikan.

Merupakan fakta yang tidak bias dipungkiri, jika Ibnu Sina adalah filosof yang terpengaruh oleh pemikiran Yunani. Implikasinya, dalam konsepsi pendidikan yang dia bangun pun cenderung mengarah pada inteletualisme. Selain itu ia juga sangat memperhatikan rasionalitas yang dibuktikan dengan keistimewaan karyanya yang rasional, obyektif, kerangka berfikir yang sistematis, dan aksperimen-aksperimen yang cermat serta mendalam. (Moh. 'Athiyah, 1994)

\section{DASAR PEMIKIRAN}

Akhlak merupakan salah satu ajaran pokok Islam yang mempunyai beberapa keistimewaan, diantaranya adalah Rasulullah saw menjadikan penyempurnaan akhlak sebagai misi utama risalah Islam, Beliau menjadikan akhlak sebagai indikator kualitas keimanan seseorang serta akhlak itu merupakan buah dari ibadah seseorang.

Namun, pada saat sekarang telah terjadi kemorosotan akhlak dalam berbagai kalangan, khuususnya pada peserta didik. Selama ini, pandangan simplistik yang berkembang di dalam masyarakat mengangggap kemerosotan akhlak, moral dan etika peserta didik disebabkan gagalnya pendidikan agama di sekolah. Memang harus diakui, dalam batas tertentu, pembelajaran pendidikan agama memiliki kelemahan-kelemahan tertentu, sejak dari jumlah jam yang sangat minim, materi pendidikan agama yang terlalu banyak teori, sampai kepada pendekatan pendidikan agama yang cenderung bertumpu pada aspek kognitif dari pada aspek afektif dan psikomotorik peserta didik.

Sejauh menyangkut krisis moral dan akhlak peserta didik, terdapat beberapa masalah pokok yang turut menjadi akar krisis mortal dan akhlak di lingkungan pendidikan, diantaranya adalah (Azyumardi Azra, 2008)

1. Arah pendidikan telah kehilangan objektivitasnya. Sekolah dan lingkungannya tidak lagi merupakan tempat peserta didik melatih diri untuk berbuat sesuatu berdasarkan nilai-nilai moral dan akhlak, di mana mereka mendapat koreksi terhadap tindakan-tindakan mereka; salah atau benar, baik atau buruk.

2. Proses pendewasaan diri tidak berlangsung baik di lingkungan sekolah. Selain fungsi pokok untuk mengisi kognisi, afeksi dan psikomotorik peserta didik, sekolah juga berfungsi sebagai tempat sosialisasi, mempersiapkan anak peserta didik meningkatkan kemampuan merespon dan memecahkan masalah-masalah dirinya sendiri maupun orang lain.

3. Proses pendidikan di sekolah sangat membelenggu peserta didik, bahkan 
juga para guru Hal ini disebabkan oleh kurikulum yang sangat berat (overloaded).

4. Beban kurikulm yang demikian berat, hampir sepenuhnya diorientasikan pada pengembangan ranah kognitif belaka. Pada pihak lain, ranah afeksi dan psikomotorik hamper tidak mendapat perhatian.

5. Kalaupun ada materi yang menumbuhkan rasa afeksi, seperti mata pelajaran agama, umunya disampaikan dalam bentuk verbal. Akibatnya bias diduga, mata pelajaran agama cenderung hanya untuk diketahui dan dihafalkan agar lulus ujian, tetapi tidak untuk diinternalisasikan dan dipraktekkan.

6. Pada saat yang sama para peserta didik dihadapkan kepada nilai-nilai yang bertentangan. Pada satu pihak mereka diajarkan para guru pendidikan agamanya untuk bertingkah laku yang baik, jujur, hemat, disiplin, dan sebagainya, tetapi pada saat yang sama, banyak orang dilingkungan sekolah justru melakukan hal-hal yang ber-tentangan.

7. Selain itu para peserta didik juga mengalami kesulitan dalam mencari contoh teladan di lingkungannya. Mereka mungkin menemukan teladan yang baik di lingkungan sekolah, di dalam diri guru tertentu. Tetapi mereka kemudian sulit menemukan keteladan di lingkungan luar sekolah.

Ketujuh masalah di atas, saling berkaitan satu sama lainnya. Dan sebab itu, upaya mengatasinya tidak bisa dilakukan secara parsial. Upaya mengatasinya tidak memadai jika hanya dilakukan di lingkungan sekolah. Kita harus menyembuhkan krisis moral dan akhlak dalam masyarakat luas, dalam rumah tangga dan lingkungannya.

\section{Biografi Ibnu Sina}

Nama lengkap Ibnu Sina adalah Abu 'Ali Al-Husain Ibn 'Abd Allah ibn Hasan ibnu 'Ali ibn Sina. Di Barat populer dengan sebutan Avicenna. Ia dilahirkan di Afsyana dekat Bukhara pada tahun $980 \mathrm{M}$ dan meninggal dunia pada tahun $1037 \mathrm{M}$ dalam usia 58 tahun. Jasadnya dikebumikan di Hamadzan. (Fu'ad Al-Ahwany, 1962).

Ibnu Sina sejak usia muda sudah menguasai beberapa disiplin ilmu, seperti matematika, logika, fisika, kedokteran, astronomi, hukum, dan lain-lainnya, bahkan pada usia 10 tahun ia telah hafal Al-Qur'an seluruhnya. Ketika anak genius ini berusia 17 tahun, dengan kepintaran yang sangat mengagumkan, ia telah memahami seluruh ilmu kedokteran yang ada pada saat itu dan melebihi siapapun juga. Karena kepintarannya ini, ia diangkat menjadi konsultan dokterdokter praktisi. Peristiwa ini terjadi ketika ia berhasil mengobati Pangeran Nuh ibn Mashur, yang sebelumnya tidak seorang dokter pun mampu menyembuhkannya. (Harun Nasution, 1973)

Di antara guru yang mendidiknya adalah Abu Abd Allah Al-Natili dan Ismail sang Zahid. Karena kecerdasan otaknya yang laur biasa, ia dapat menguasai semua ilmu yang diajarkan kepadanya dengan sempurna, bahkan melebihi sang guru.

Setelah guru-gurunya kewalahan, Ibnu Sina menjadi bingung mencari tempat untuk memuaskan kehausan belajarnya yang tidak kunjung terpenuhi. Telah disebutkan, karena keberhasilannya mengobati Pangeran Nuh ibn Manshur, Ibnu Sina diberi kebebasan belajar di perpustakaan istana, Kutub Khana. Di sinilah ia melepaskan dahaga belajarnmya siang malam sehingga semua ilmu pengetahuan dapat ia kuasai dengan sempurna. (Sirajuddin Zar, 2004)

Keberhasilan Ibnu Sina ini didukung oleh minat belajarnya yang luar biasa dan kegeniusan otaknya, di 
samping adanya kebebasan yang diberikan para penguasa. Menurut Nurcholish Madjid, di snilah letaknya keberuntungan dunia Islam. Dari segi politik dunia Islam boleh dikatakan telah porak poranda, akibat para penguasa saling bersaing dan saling mengungguli, namun mereka tetap mendorong dan melindungi kegiatan intelektual dan ilmiah. Oleh karena itu, berbagai kegiatan seperti ini berkembang bagaikan cendawan di musim hujan. (Nurcholish Madjid, 1984)

Ibnu Sina secara tidak langsung berguru kepada Al-Farabi, bahkan dalam otoboigrafinya disebutkan tentang utang budinya kepada Guru kedua ini. Hal ini terjadi ketika ia kesulitan untuk memahami matematika Aristoteles, sekalipun telah ia baca sebanyak 40 kali dan hamper hafal di luar kepala. Akhirnya, ia tertolong berkat bantuan risalah kecil AlFarabi. Anekdot ini juga dapat diartikan bahwa Ibnu Sina adalah seorang pewaris filsafat Neoplatonisme Islam yang dikembangkan Al-Farabi. Dengan istilah lain, Ibnu Sina adalah pelanjut dan pengembang filsafat Yunani yang sebelumnya telah dirintis oleh Al-Farabi dan dibukakan pintunya oleh Al-Kindi.

Atas keberhasilan Ibnu Sina dalam mengembangkan pemikiran filsafat sehingga dapat dinilai bahwa filsafat di tangannya telah mencapai puncaknya, dan karena prestasinya itu, ia berhak memperoleh gelar kehormatan dengan sebutan al-Syikh al-Ra'is (Kiyahi Utama). (Nurcholish Madjid, 1984)

Sebagai pemikir yang inovatif dan kreatif pada umumnya, Ibnu Sina tidak terlepas dari cobaan yang menimpa dirinya. Ketika pustaka istana Kutub Khana terbakar, ia dituduh membakarnya, supaya orang lain tidak dapat menguasai ilmu yang ada di sana. Cobaan lain, bahwa ia pernah dipenjarakan oleh putra Al-Syams Al-Dawlah, hanya sematamata kedengkian atau ketidaksenangan. Setelah beberapa bulan, ia dapat me- loloskan diri dari penjara dan lari ke Isfahan dan disambut oleh amirnya dengan segala kehormatan. Di kota inilah ia mengabdikan dirinya sampai akhir hayatnya.

\section{Beberapa Konsepsi Ibnu Sina tentang Pendidkan Islam}

Ibnu sina banyak memberikan saham dalam meletakan dasar-dasar pendidikan Islam, yang amat berharga sekali dan tidak kecil pengaruhnya terhadap pendidikan Islam dewasa ini. Diantara pandangan Ibnu Sina terhadap pendidikan adalah sebagai berikut:

\section{a. Tujuan Pendidikan}

Pandangan klasik tentang pendidikan, umumnya dikatakan sebagaia pranata yang mempunyai tiga tujuan. Pertama, menyiapkan generasi muda untuk memegang peranan-peranan tertentu dalam masyarakat di masa yang akan dating. Kedua, mentransfer pengetahuan sesuai dengan peranan yang diharapakan. Ketiga, mentransfer nilainilai dalam rangka memelihara keutuhan dan kesatuan masyarakat sebagai prasyarat bagi kelangsungan hidup masyarakat dan peradaban manusia. (Hasan Langgulung, 1980).

Menurut Ibnu Sina, tujuan pendidikan adalah untuk mencapai kebahagiaan ( $s a^{\prime}$ 'adat), kebahagiaan dicapai secara bertingkat, sesuai dengan tingkat pendidikan yang dikemukakannya, yaitu kebahagiaan pribadi, rumah tangga, masyarakat, manusia secara menyeluruh dan kebahagiaan akhir yaitu akhirat. (Jalaluddin, 1994). Kebahagiaan yang menjadi tujuan dari pendidikan ini dapat diperoleh oleh setiap manusia dengan cara bertahap. Pada awalnya secara individu, yang akan tercapai bila individu memiliki kemuliaan akhlak. Bila individu sudah berakhlak, maka akan tercapai kebahagiaan rumah tangga. Kemudian jika masing-masing rumah tangga berpegang pada prinsip akhlak 
mulia, maka akan tercapai kebahagiaan dalam masyarakat, dan ini akan berimbas kepada kebahagiaan manusia secara menyeluruh.

Tujuan pendidikan harus diarahkan kepada pengembangan seluruh potensi yang dimiliki seseorang ke arah perkembangannya yang sempurna, yaitu perkembangan fisik, intelektual dan budi pekerti. Lebih lanjut, Ibnu Sina berpandangan bahwa tujuan pendidikan adalah untuk kemandirian dalam mengemban beban hidup dan memberi kemanfaatan kepada masyarakat dengan jalam membina tiap anggota masyarakat dengan pekerjaan mereka dengan baik. Apabila anak sudah cukup cakap dalam bidang kepandaianya, maka asuhan selanjutnya ialah memberi lapangan usaha baginya dan membimbing yang belajar hidup dari kepandaiannya itu. (Busyairi Madjidi, 1997).

Adapun terkait dengan tujuan pendidikan yang bersifat Islami, hendaknya dengan pendidikan jasmani atau olah raga anak diarahkan agar terbina pertumbuhan fisiknya dan cerdas otaknya. Sedangkan dengan pendidikan budi pekerti, diharapkan anak-anak memiliki kebiasaan bersopan santun dalam pergaulan hidup sehari-hari, dan dengan kesenian diharapkan dapat mempertajam perasaannya dan meningkatkan daya khayalnya. (Ibnu Sina, 1994)

Ibnu Sina mencoba menyelaraskan tujuan pendidikan, baik tujuan jangka pendek atau tujuan duniawi, maupun tujuan jangka panjang yaitu tujuan ukhrawi. Setelah anak didik mengalami proses pendidikan, diharapkan ia mampu menghadapi kehidupannya sehari-hari sekaligus kelak diharapkan dia akan mendapatkan kebahagiaan di akhirat sesuai ajaran agama islam.

Jadi, bagi Ibnu Sina tujuan pendidikan Islam itu adalah membentuk manusia yang berkepribadian dan berakhlak mulia. Ukuran akhlak mulia dijabarkan secara luas yang meliputi seluruh aspek kehidupan manusia. Aspek-aspek yang menjadi syarat bagi terwujudnya suaru sosok pribadi berakhlak mulia meliputi aspek pribadi, social, dan spiritual. Ketiganya harus berfungsi secara integral dan komprehensif

\section{b. Sifat Ideal yang harus dimiliki Guru}

Menurut Ibnu Sina, guru yang baik adalah seorang pendidik yang cerdas, bijaksana, taat beragama, mengerti pembinaan akhlak, budi pekerti, pandai membimbing anak-anak, tidak banyak ngobrol dihadapan anak-anak, tidak kaku dank eras, bermuka manis dan ramah, punya pretise (harga diri), bersih dan rapi. (Busyairi Madjidi, 1997). Tambahnya, guru sebaiknya dari kaum pris terhormat, mendalami ilmu agama, orang yang saleh, bertaqwa kepada Allah dan rasul. Guru harus takut melakukan perbuatan yang dilarang Allah, selalu mengevaluasi dirinya terhadap waktu mengajar yang dinilai kurang efektif dalam proses belajar. Guru tidak boleh seorang yang ahteis atau kafir, sebab guru yang mendalami ilmu agamanya akan memiliki tanggung jawab dan tulus, konsisiten dalam menjalankan tugas dan terpercaya. Sedangkan yang ahteis atau kafir akan sulit diharapkan ktulusan hatinya. (Moh. 'Athiyah, 1994)

Guru merupakan panutan bagi murid-muridnya, sehingga ia selalu ditiru baik ucapan, perbuatan, pendirian, atau sikap dan pergaulannya. Di samping itu, hendaknya seorang guru mengetahui dan mengenal betul dunia anak-anak, sehingga bijaksana dalam mendidik, mengenal minat dan bakat mereka dan dipercaya dalam membina pertumbuhan jiwanya.

\section{c. Hukuman (Sanksi)}

Hukuman merupakan salah satu alat pendidikan. Namun di kalangan para pendidik terdapat pro dan kontra dalam penggunaannya. Orang yang tidak me- 
nyukainya berpendapat bahwa hukuman merupakan kekeliruan dalam sistem pendidikan, sementara yang setuju berpendapat bahwa kodrat manusia tidak selamanya bias berbuat baik. Sering manusia lalai dalam melaksanakan perbuatannya. Dengan demikian, perlu diadakan perbaikan dengan cara yang luar biasa, diantaranya melalui hukuman. (Muhammad Munir Mursi, 1997).

Ibnu Sina pada dasarnya tidak berkenan menggunakan hukuman dalam kegiatan pendidikan, karena dia sangat menghargai martabat manusia. Jika terpaksa harus mendidik dengan hukuman, sebaiknya diberi peringatan dan ancaman terlebih dahulu. Hukuman harus dilaksanakan dengan ekstra hatihati. Dia menyadari sepenuhnya bahwa manusia memiliki naluri ingin disayang dan tidak suka dikerasi. Jangan menindak anak dengan kekerasan, tetapi dengan ketulusan hati. (Ibnu Sina, 1994)

Masih dalam penerapan hukuman terhadap anak didik, Ibnu Sina berpendapat bahwa kewajiban pertama ialah mendidik anak dengan sopan santun dan membiasakannya dengan sikap terpuji sejak mulai disapih sebelum kebiasaan jelek mempengaruhinya. (Ali Jumbulati, 2002)

Ibnu Sina juga menyarankan hendaknya hukuman seperti cambukan dapat diterapkan setelah anak tidak mempan lagi dengan sanksi peringatan keras atau cara lain. Pentingnya hukuman fisik ini diterapkan agar teman-temannya dapat mengambil pelajaran yang baik dan takut melakukan kesalahan serupa. Jika hukuman memang harus diberikan, maka kita harus hati-hati dan penuh pertimbangan disaat akan menerapkan hukuman (sanksi) kepada anak, hendaknya bukan hukuman yang berupa cercaan atau cambukan yang keras tapi perlakuan halus, persuasive, dan penuh kasih sayang.

Dengan demikian dapat dipahami bahwa bagi Ibnu Sina, hukuman itu boleh diberikan jika memang sangat diperlukan, tetapi harus dengan cara yang ekstra hati-hati.

\section{KONSEP PENDIDIKAN AKHLAK}

Ibnu Sina sangat memperhatikan segi akhlak dalam pendidikan, sehingga yang menjadi fokus perhatian dari pemikiran filsafat pendidikan adalah mendidik anak dengan menumbuhkan kemampuan beragama yang benar, karena pendidikan agama merupakan landasan bagi pencapaian tujuan pendidikan akhlak.

Ibnu Sina mengakui adanya pengaruh mengikuti, meniru, atau mencontoh tauladan baik dalam proses pendidikan di kalangan anak usia dini terhadap kehidupan mereka. Karena secara tabiat anak mempunyai kecenderungan mengikuti, meniru yang dilihat, di rasa dan di dengar. Ia menyatakan, jika anak berada di maktab, bergaul dengan sesama anak yang berakhlak terjadi interaksi edukatif, satu sama lain saling meniru dan dengan demikian ia menjadi dasar budinya. (Ali Jumbulati, 2002)

Ibnu Sina berusaha mengembangkan kecenderungan fitrah anak dalam pergaulannya dengan anak lainnya, dan menjadikannya sebagai alat untuk pendidikan yaitu dengan cara membatasi pergaulan anak dengan anak-anak lain yang berakhlak baik. Dengan demikian ia membatasi tujuan pergaulan anak dengan anak-anak yang lain, karena pada anak terdapat suasana pergaulan yang membangkitkan antusiasme diantara mereka.

Ibnu Sina berpandangan bahwa pertama-tama sebaiknya anak itu belajar Al-Qur'an. Ketika anak tersebut telah siap secara fisik dan mental untuk belajar, pada waktu yang sama ia sebaiknya belajar huruf abjad, diajarakan dasar-dasar pendidikan agama, dan belajar syair yang dimulai dengan yang pendek-pendek agar mudah dihafal. 
Kemudian diajarkan pula syair-syair pilihan yang berisi tentang keutamaan budi pekerti, penghargaan tentang ilmu, celaan tentang kebodohan, dorongan berbuat baik kepada kedua orang tua, melakukan perbuatan melayani tamu dengan baik. (Athiyah Al-Abrasyi, 1994).

Keutamaan akhlak dari jiwa anakanak tumbuh dari perilaku baik dalam pergaulannya. Akhlak yang baik tumbuh dari kebaikan pergaulan, begitu pula sebaliknya. Akhlak yang baik itu akan mempengaruhi kesehatan mental dan fisik secara keseluruhan. (Ibnu Sina, 1994). Dari pandangan ini dapat dipahami bahwa dalam pandangan Ibnu Sina, akhlak merupakan sesuatu yang diusahakan dan bukan warisan yang dapat membentuk tanpa usaha untuk mewujudkannya, Manusia bisa melakukannya melalui pendidikan, pembiasaan dan menelaah dari perilaku orang lain.

Dilihat dari segi metode pendidikan akhlak, bagi Ibnu Sina pentingnya pembicaraan antara anak, bahwa pembicaraan antara anak dengan anak berguna sekali untuk mengungkapkan dorongan pikirannya dan melepaskan tali ikatan yang menghalangi perkenalan mereka. Karena setiap anak hanya membicarakan tentang sesuatu yang paling menyenangkan dalam pengalaman mereka, dan sesuatu yang paling asing dari apa yang didengarnya. Nampaknya Ibnu Sina cenderung menerapkan metode diskusi. Karena melalui metode ini, anak diharapkan aktif dalam proses pembelajaran, seperti mengajak anak untuk berbincang-bincang dengan temannya. Karena dengan cara ini, peserta didik diharapkan dapat mengembangkan potensi nalar dan sosialnya. Selain itu, Ibnu sina juga mengembangkan pembiasaan dan penciptaan lingkungan yang kondusif akhlaki.

Bagi Ibnu Sina, melalui metode diskusi ini diharapkan mampu membangkitkan aktivitas berbicara anak dan kemampuan mengungkapkan isi hati mereka. Karena ia menganggap bahwa pembicaraan di kalangan anak merupakan persiapan akal anak untuk berpikir dan berdiskusi, dan membuka jalan untuk mendapatkan pemahaman yang mendalam. Kegiatan berbincang-bincang antar anak juga dapat menambah perbendaharaan bahas dalam pikiran mereka.

Nampaknya, dalam menentukan metode pendidikan terhadap anak, Ibnu Sina sangat menekankan pentingnya perhatian pendidik terhadap psikologi anak. Karena hal ini sangat menentukan dengan pemilihan metode yang tepat dalam pengajaran, sukses dalam menunaikan tugas dan mengatasi problematika pendidikan dan pengajaran. Ini juga terkait masalah meneliti tingkat kecerdasan, karakteristik, bakat, kemudian memeliharanya dalam rangka menentukan pilihan yang disenangi untuk masa depan sesuai dengan kesenangan tersebut.

Dalam kaitannya dengan perhatian psikologi anak, Ibnu Sina mensyaratkan agar pendidikan memperhatikan bercanda ria anak dengan teman-temannya. Karena ghal ini sangat berguna untuk pertumbuhan dan perkembangan akal fikirannya, Percakapan anak anak dalm pergaulannya akan mendorongnya untuk menghafal dan menceritakan kembali. Aktivitas ini merupakan media transformasi pendididkan penanaman kebiasaan baik di kalangan anak didik. (Athiyah alAbrasyi, 1994)

Di samping itu, Ibnu Sina menggunakan syair sebagai salah satu sarana pendidikan akhlak, karena menurutnya syair itu mengandung nilai akhlak. Dijadikannya syair sebagai media pendidikan bagi Ibnu Sina, barangkali kembali kepada pribadinya sebagai seorang filsosof dan tabib yang berjiwa pendidik atau pendidk yang berjiwa tabib, yang menyebabkan ia menjadi penyair. Dari ungkapan syair-syair Ibnu 
Sina, ia mengarahkan kepada filsafat akhlak yang kemudian dijadikan sebagai salah satu alat pendidikan.

Sebagai seorang filsosof, pemikir metafisis, maka syair-syairnya sangat terpengaruh oleh corak pemikirannya, di samping terpengaruh oleh permasalahan kemanusiaan yang mendorong kepada makrifat kepada Allah. Hal ini tergambar dalam pemecahan problema-problema tentang eksistensi alam semesta, tentang hidup dan mati, qadla dan qadar, kegaiban dan kenyataan panca indera, baik dan buruk, kenikmatan dan kesengsaraan. Di antara ungkapan kata yang terpancar dalam syairnya ialah tentang jiwa nabati, perasaan panca indera, alam nasut dan lahut (ketuhanan), Causa Prima (Sebab Pertama) dan lain-lain. Maka tidaklah heran jika Ibnu Sina menganggap penting syair dan isinya untuk dijadikan sebagai alat pendidikan.

Dalam syair-syairnya, Ibnu Sina mengemukakan tentang keutamaan akhlak budaya, memuji ilmu, mencela kebodohan dan kemiskinan, mendorong semangat berbuat baik terutama kepada kedua orang tua, yang pada intinya dalam syairnya ia ingin mendorong terwujudnya akhlak mulia. (Ali- AlJumbulati, 2002)

Dalam pendidikan akhlak ini, Ibnu Sina menghubungkan pendidikan akhlak dengan kesehatan jasmani dan rohani, serta memelihara kewajiban sesuai dengan tuntutan pendidikan anak. Dalam hal ini, ia menegaskan bahwa wajib diupayakan dengan sungguh-sungguh memelihara akhlak anak dengan cara tidak menimpakan amarah secara berlebihlebihan, atau menakut-nakuti. Tetapi sebaliknya harus dipikirkan bagaimana agar apa yang disukai anak, apa yang menjadi hobbinya bisa didekatkan kepada anak. Sedangkan apa yang dibenci jauhkanlah dari anak, jangan dihadapkan anak pada kesulitan, sebisanya harusa diusahakan kemudahan untuk anak dalam mengembangkan keahliaanya.

Demikianlah pandangan Ibnu Sina tentang pendidikan, yang mana dari pemikirannya ini dapat kita pahami bahwa ia sangat mementingkan pendididkan akhlak. Pendidikan akhlak merupakan factor asasi bagi terwujudnya tujuan pendidikan.

\section{PENUTUP}

Sebagai seorang filosof yang sangat memperhatikan masalah pendidikan, Ibnu Sina banyak memberikan saham dalam meletakan dasar-dasar pendidikan Islam, yang sangat berharga sekali dan tidak kecil pengaruhnya terhadap pendidikan Islam dewasa ini. Dalam pendidikan, ia sangat mementingkan pendidikan akhlak yang mengintegrasikan nilai-nilai idealitas dengan pandangan pragmatis. Hal ini terlihat dari pemikirannya yang sudah diuraikan di atas. Seperti penddidikan anak harus dimulai dengan pendidikan Al-Qur'an tetapi dengan tidak memberatkan jasmani dan akal pikirannya. Mengembangkan pendidikan akhlak ini melalui metode diskusi dan pergaulan anak, karena menurutnya akhlak anak sangat dipengaruhi oleh lingkungan dimana ia berada, karena pada dasarnya anak mempunyai sifat suka meniru. Dan dalam menentukan metode pendidikan terhadap anak, seorang pendidikan harus memperhatikan psikologi anak. Sedangkan untuk sarana pendidikan akhlak ini, ia menggunakan syair sebagai salah satu alat pendidikan, karena menurutnya melalui syair kita bisa menyampaikan banyak nilai yang berkaitan dengan keutamaan akhlak mulia. 


\section{DAFTAR RUJUKAN}

Ali Al-Jumbulati danAbdul Futuh AtTuwaanisi, 2002, Perbandingan Pendidikan Islam, Jakarta: Rineka Cipta

Aden Wijdan SZ dan Muslih Usa, 1997, Pendidikan Islam dalam Peradaban Industrial, Jakarta: Aditya Media

Busyairi Madjidi, 1997, Konsep Pendidikan Para Filosof Muslim, Jogjakarta: al-amin Press

Jalaluddin, dkk,1994, Filsafat Pendidikan Islam, Jakarta: Raja Grafindo Persada

Muhammad Jawwad Ridha, 2002, Tiga Aliran Utama Pendidikan Islam, Jogyakarta: Tiarawacana

Samsul Nizar, 2002, Filsafat Pendidikan Islam, Jakarta: Ciputat Press

Toto Suharto, 2006, Filsafat Pendidikan Islam, Jogjakarta: Ar-Ruzz Media

Moh. Athiyah al-Abrasyi, 1994, AlTarbiyah al-Islamiyah wa Fala- sifatuha, terj. Samsudin Asrofi, dengan judul: Pokok-Pokok Pikiran Ibnu Sina Tentang Pendidikan, Jogjakarta: Sumbangsih Offset.

Ibnu Sina, 1994, al-Qanun fi al-Tib, Mesir, dar al-Fikr

Muhammad Munir Mursi, 1997, AlTarbiyah al_Islamiyah Ushuluha wa Taqwaruha fi al-Bilad alArabiyah, Mesir, "Alamu Qutub

Nurcholish Madjid, Khazanah Inteletual Islam, 1984, Jakarta: Bulan Bintang

Harun Nasution, Falsafat dan Mistisisme dalam Islam, 1978, Jakarta: Bulan Bintang

Madjid Fakhri, Sejarah Filsafat Islam. Terj. Mulyadi Kertanegara, 1987, Jakarta: Pustaka Jaya

Sirajuddin Zar, Filsafat Islam, Filosof dan Filsafatnya, 2004, Jakarta: Rajawali Press. 